\title{
Scanlation e o poder do leitor-autor na tradução de mangás
}

\section{Scanlation and the power of the reader- author in manga translation}

\author{
Sabrina Moura Aragão*
}

Resumo: 0 presente trabalho propõe uma reflexão inicial acerca da scanlation, prática tradutória exercida por fãs de mangá de forma não profissional. Em se tratando de uma atividade motivada por interesses pessoais ou coletivos de grupos de leitores que se inserem em um contexto específico, interessa-nos observar as características e estratégias utilizadas em tais traduções e no que elas se diferenciam em relação às traduções publicadas pelas editoras. Para tanto, analisaremos o décimo volume do mangá Fairy Tail, de Hiro Mashima, com as respectivas scanlations feitas por fãs brasileiros e as traduções publicadas pela editora JBC. Atentaremos, ainda, para questões de identidade em tradução, tendo em vista os aspectos próprios dos mangás e seu público leitor.

Palavras-chave: Scanlation; mangá; tradução de histórias em quadrinhos.

Abstract: This paper proposes an initial reflection on scanlation, a translation practice exercised by manga fans unprofessionally. As beeing characterized as an activity motivated by personal or collective interests of groups of readers that are embedded in a specific context, we are interested in observing the characteristics and strategies used in these translations and in which point they differ in relation to translations made by publishers. We will analyze the tenth volume of the manga Fairy Tail, by Hiro Mashima, and both the scanlations made by Brazilian fans and

\footnotetext{
* Universidade de São Paulo - Doutoranda junto ao programa de Estudos da Tradução. Universidade Estadual de Londrina - Professora assistente junto ao Departamento de Letras Estrangeiras Modernas. Contato: sabrina.aragao@usp.br / sabrina.aragao@uel.br
} 
ARAGÃo, S. M. - Scalation e o poder do leitor-autor na tradução de mangás

those published by JBC publisher. We also intend to analyze identity issues in translation, due to specific aspects of manga and its readers.

Keywords: Scanlation; manga; comics translation.

\section{Introdução}

Considerando-se o avanço dos estudos tradutológicos, em constante ampliação, um campo que vem se firmando como fonte de pesquisa científica autônoma desde a década de 80 , observa-se o surgimento de novas áreas de estudo específicas na medida em que as práticas de comunicação se desenvolvem; nesse sentido, com o surgimento de novas formas de mídia, surgem também novas formas de se fazer - e de se pensar - a tradução. Por esse motivo, os estudos tradutológicos podem ser considerados um campo em constante expansão, pois, graças ao surgimento de novas formas de comunicação em um mundo globalizado, novas fontes de pesquisa se desenvolvem, alimentando um ciclo que só tende a enriquecer dentro do contexto dos estudos tradutológicos. Diante de tal perspectiva, este artigo busca analisar uma forma de tradução relativamente recente denominada scanlation, que trata da tradução de histórias em quadrinhos feita por fãs, sobretudo de mangás japoneses. Jüngst (2014: 61) define a scanlation como "um processo no qual as páginas dos mangás japoneses são digitalizadas e depois traduzidas e apresentadas na Internet por fãs de mangás”1 (tradução nossa).

A scanlation surgiu por volta dos anos 90, porém a investigação científica dessa prática ainda está em fase inicial. O termo scanlation foi

\footnotetext{
1 "a process by which pages from Japanese manga are scanned and then translated and presented on the Internet by manga fans".
}

TradTerm, São Paulo, v. 27, Setembro/2016, pp. 75-113

www.usp.br/tradterm

http://www.revistas.usp.br/tradterm/index 
ARAGÃo, S. M. - Scalation e o poder do leitor-autor na tradução de mangás

cunhado pelos fãs de mangás japoneses e é uma contração das palavras em inglês scan e translation em referência ao processo de elaboração das obras, já que os mangás japoneses são escaneados e em seguida traduzidos por meio da edição das imagens em programas de computador específicos. No Brasil, os sites especializados nesse tipo de tradução também mencionam o termo scantrad, apesar de o termo em inglês também ser recorrente.

\section{A tradução de mangás}

As histórias em quadrinhos são uma forma de arte que se reinventa constantemente, atraindo um público cada vez maior e mais amplo, em outras palavras, com o desenvolvimento estético-formal da arte, novas audiências passam a se interessar por essa forma de mídia. Grande parte dessa produção passa, necessariamente, pela tradução, principalmente no Brasil, onde o mercado editorial tende a importar sucessos internacionais, dentre os quais destacam-se os quadrinhos europeus (França, Bélgica e Itália, por exemplo), norte-americanos e sobretudo japoneses, como é o caso dos mangás. Podemos citar como exemplos de sucessos internacionais, logo, traduzidos, algumas obras de quadrinhos com teor biográfico e histórico, como o vencedor do prêmio Pulitzer, Art Spiegelman, autor de Maus; Marjani Satrapi, autora de Persépolis e que teve sua obra transformada em longa de animação; o reverenciado Will Eisner e seu Ao coração da tempestade e, Joe Sacco, com o aclamado Palestina, este último mais próximo da linguagem jornalística no relato de fatos históricos do que os anteriores; além dos mangás de enorme sucesso, não só no Japão, mas também na maioria os países onde foram publicados, como Naruto, de Masashi Kishimoto, One Piece, de Eiichiro Oda e Dragon Ball, de Akira Toriyama.

De acordo com Jüngst (2014: 50), os mangás formam o maior segmento de tradução de histórias em quadrinhos no Ocidente. Ainda segundo a autora, 
ARAGÃo, S. M. - Scalation e o poder do leitor-autor na tradução de mangás

o processo de tradução de mangás possui uma série de especificidades, sendo uma delas o forte interesse e influência dos grupos de fãs, que são altamente críticos das traduções, mesmo quando não falam japonês. Jüngst (2014: 60) descreve o perfil desses leitores:

Os fãs de mangás têm consciência de que estão lendo traduções. Alguns deles aprendem japonês [...] [e] esperam que as traduções lhes proporcionem algo que se pareça o máximo possível com o original. [...] Eles querem que o mangá pareça japonês, e isso se estende a alguns aspectos linguísticos e pictóricos. (idem, ibidem)

Ora, diante de tal perfil, a prática da scanlation se contextualiza, uma vez que tais traduções buscam atender à demanda dos fãs, não só no aspecto linguístico, como também no que se refere à velocidade em que as páginas traduzidas por estes grupos são disponibilizadas na Internet, conforme veremos no próximo item.

\section{Scanlation e os fãs}

Conforme mencionado acima, as scanlations são traduções de histórias em quadrinhos japonesas - os mangás - feitas por fãs que não são tradutores profissionais, assim, esses fãs traduzem as obras diretamente do japonês porque as apreciam e desejam que outros leitores tenham acesso aos quadrinhos que ainda não foram publicados no país. O que motiva a escolha de uma obra a ser traduzida é o gosto pessoal do tradutor que a distribui gratuitamente na internet para que outros fãs, que não têm acesso ou não sabem japonês, possam desfrutar da obra como ele. Trata-se de uma atividade teoricamente sem fins lucrativos, pois não há remuneração aos tradutores e apenas se traduz o que ainda não foi licenciado para publicação no país. É interessante notar ainda que os scanlators valorizam o 
ARAGÃo, S. M. - Scalation e o poder do leitor-autor na tradução de mangás

"voluntariado" de seus trabalhos ao mesmo tempo em que defendem a propriedade intelectual das traduções, pois todas as obras escaneadas possuem créditos e até mesmo marcas d'água com o logotipo da equipe responsável pela tradução e distribuição.

Segundo Simó (2005) os scanlators são, em geral, estudantes universitários que veem a tradução de mangás como um hobby. As scanlations são feitas por falantes nativos que têm o japonês como segunda ou terceira língua, isto é, as traduções não são feitas por leitores japoneses interessados em divulgar mangás no exterior ou treinar o inglês. Conforme afirmam Hirata \& Gushiken (2011), as línguas mais usadas na scanlation são o inglês, o espanhol, o francês e o português. Vale ressaltar que, de acordo com estes autores, há também retraduções do inglês e/ou do espanhol na falta do original em japonês e, segundo a ética dos scanlators, é obrigatório citar a fonte da tradução se o texto usado como base pertencer a um outro grupo de scanlation.

Sabe-se que os mangás possuem uma infinidade de gêneros: aqueles direcionados ao público infantil, adulto, para meninos, para meninas, mangás de esporte, mangás eróticos etc., assim, alguns grupos se especializam na tradução de um determinado gênero. Não há limites para as scanlations, em geral, as obras escolhidas são aquelas de grande sucesso no Japão, mas que ainda não foram publicadas no país dos scanlators, porém tudo depende da iniciativa do fã que resolve traduzir e distribuir sua obra preferida na internet.

Na maioria das vezes, as scanlations são feitas por um grupo de pessoas que se divide em funções como em uma editora: tradutores, revisores e editores, com direito a créditos e reconhecimento por parte dos leitores.

Prazos e funções são estabelecidos como em uma empresa, de modo que o grupo mantenha um ritmo razoável de lançamentos e mantenha um bom relacionamento com os leitores. (HIRATA \& GUSHIKEN 2011: 4)

TradTerm, São Paulo, v. 27, Setembro/2016, pp. 75-113

www.usp.br/tradterm

http://www.revistas.usp.br/tradterm/index 
ARAGÃo, S. M. - Scalation e o poder do leitor-autor na tradução de mangás

Segundo Lee (2010), o perfil dos scanlators abrange desde aqueles que agem de forma independente e individualmente até grupos de 50 membros. Os scanlators adotam pseudônimos e revezam as funções em cada volume, assim, em um mesmo grupo, diferentes pessoas traduzem a obra. Trata-se de um trabalho em equipe que prevê a participação do público, haja vista os fóruns de discussão e também a iniciativa dos tradutores em deixarem um espaço para que o leitor opine não só sobre a obra, mas principalmente sobre a tradução. Conforme bem apontado por O’Hagan (2009), a scanlation é um trabalho de tradução colaborativo online. Tal característica configura a scanlation como uma atividade extremamente dinâmica e em constante transformação, algo impensável em uma tradução impressa, por exemplo.

Por se tratar de um trabalho realizado por fãs, não há critérios tradutológicos pré-definidos nem técnicos profissionais, ao mesmo tempo em que também não há correções, imposições ou censura impostas por uma editora; desse modo, é comum observar a presença de gírias, expressões populares, palavrões e erros de sintaxe e ortografia. No que se refere à linguagem das scanlations, observa-se, muitas vezes, estruturas sintáticas pouco comuns na língua de chegada, o que indica uma tradução literal da língua japonesa. Tal característica, segundo Simó (2005) é bem vista pela maioria dos leitores por indicar uma relação de semelhança com o original, assim, o leitor tem a sensação de estar lendo exatamente o que foi escrito em japonês sem nenhum tipo de adaptação. A presença de decalques também é comum, desse modo, muitas palavras não são traduzidas. Uma hipótese para o uso recorrente de decalques é que os scanlators pressupõem um certo conhecimento de língua e cultura japonesas de seus leitores que, assim como eles, também são aficionados pela cultura pop daquele país que tem o mangá como um de seus maiores expoentes. Há também notas explicativas sobre aspectos culturais e/ou linguísticos, como a alusão a determinadas festas ou trocadilhos. Em resumo, Simó (2005: 29) elenca as principais características da scanlation da seguinte forma:

TradTerm, São Paulo, v. 27, Setembro/2016, pp. 75-113

www.usp.br/tradterm

http://www.revistas.usp.br/tradterm/index 
ARAGÃo, S. M. - Scalation e o poder do leitor-autor na tradução de mangás

\begin{tabular}{|l|l|}
\hline & \multicolumn{1}{|c|}{ Scanlation } \\
\hline Formato & $-. j p g, . j p e g$, .pdf, .bmp \\
& - Disponível para download em zip ou por partes. \\
& -180 páginas/volume em vários arquivos. \\
\hline Grafismo & - Onomatopeias no original (sem tradução nem retoque \\
& gráfico) \\
& - Omissão de páginas de copyright e folhas de rosto \\
\hline Conteúdo & - Neologismos e estruturas agramaticais \\
& - Nomes originais sem adaptação \\
& - Elementos culturais sem adaptação \\
& - Sufixos honoríficos japoneses sem adaptação \\
& - Notas de rodapé para resolver referentes culturais \\
\hline
\end{tabular}

\section{Scanlation e o mercado editorial}

Em termos jurídicos, a scanlation é considerada uma prática ilegal, pois viola os direitos de propriedade intelectual por meio da alteração e distribuição das obras sem autorização dos autores. Apesar disso, as scanlations vêm sendo feitas desde meados dos anos 90 e continuam a crescer juntamente com a popularidade dos mangás no mundo ocidental. Pode-se dizer que essa prática é, de certa forma, tolerada pela indústria por não possuir fins lucrativos; a scanlation funciona ainda como publicidade para uma determinada obra, assim, a editora pode avaliar a popularidade do mangá antes de comprar os direitos de distribuição por meio de sites especializados na distribuição de scanlation.

De acordo com O'Hagan (2009) toda tradução feita por fãs, não só a scanlation, mas também os fansubs, que são a legendagem de séries animadas, é também uma forma de protesto contra as indústria midiática, 
ARAGÃo, S. M. - Scalation e o poder do leitor-autor na tradução de mangás

pois muitas vezes as editoras demoram anos para começar a publicar um determinado título. A scanlation frequentemente é a única forma dos leitores terem acesso a obras menos populares de seus artistas favoritos, pois há grupos especializados em traduzir um autor específico.

Conforme apontado no item anterior, as traduções das scanlations costumam ser literais, mantendo elementos culturais e palavras da língua japonesa. Tal aspecto também é uma forma de combater as traduções oficiais que tendem a adaptar o texto à realidade do leitor ocidental, desse modo, muitos elementos típicos da cultura nipônica não aparecem na obra traduzida pelas editoras, o que desagrada os aficionados em mangá. Segundo Douglass et al. (2011), outro aspecto relevante a ser considerado na publicação trata da edição das imagens, pois é costume das editoras manipular os desenhos por meio do retoque de sombras e linhas, destaques para planos de fundo, ou a substituição das onomapatopeias em japonês (que têm uma função gráfica importante por comporem o cenário); tais medidas também não são bem vistas pelos fãs, uma vez que há uma interferência nos valores de produção artística presentes no original.

Em contrapartida, as editoras não podem ignorar 0 peso das scanlations, assim, elas de veem obrigadas a considerar o que os fãs já leram e o que já foi dito sobre um determinado mangá no momento de tomar decisões sobre a tradução no meio profissional. De acordo com Simó (2005), existem tradutores profissionais de mangá que utilizam as scanlations como apoio didático em outros idiomas como o inglês, ao invés de partir unicamente do original em japonês.

Outra forma que o mercado encontrou de aproveitar a prática de scanlation é o recrutamento de scanlators para trabalhar nas editoras:

Aproveitando a habilidade adquirida pelos fãs em tarefas como tradução e edição nos mangás digitais de distribuição não autorizada, grupos editoriais voltados apenas para venda de conteúdo digital passaram a atrair os membros de scanlators para fazer parte da indústria de quadrinhos digitais. Um dos primeiros a

TradTerm, São Paulo, v. 27, Setembro/2016, pp. 75-113

www.usp.br/tradterm

http://www.revistas.usp.br/tradterm/index 
ARAGÃo, S. M. - Scalation e o poder do leitor-autor na tradução de mangás

abrir suas portas para o novo tipo de negócio é o site Digital Manga Guild, que iniciou a procura por tradutores e editores com experiência em scanlation, um dos requisitos para participar do processo de seleção. (HIRATA \& GUSHIKEN 2011: 10)

Adotando tal medida, as editoras estabelecem uma nova relação com os fãs, pois ao invés de iniciar uma batalha judicial contra os grupos de scanlation, estabelece-se uma relação de colaboração que pode ser mais lucrativa para o mercado.

No que se refere aos fóruns de discussão na rede e sites especializados em scanlation, percebe-se um senso de ética entre os leitores e os tradutores, uma vez que estes incentivam a compra do material impresso original em japonês a ser escaneado como uma forma de apoiar e prestigiar o trabalho do autor. Com a internet, a compra de mangás originais do Japão é facilitada e, além disso, há inúmeras lojas especializadas que importam as obras e as disponibilizam. Outra medida praticada pela maioria dos scanlators é a interrupção do trabalho de scanlation a partir do momento em que a obra é licenciada para venda no país. A compra do álbum impresso também é uma forma de reconhecimento e incentivo do trabalho do autor da obra, o que é incentivado nos sites de scanlation, que indicam, inclusive, o nome das editoras que detêm os direitos de distribuição do mangá, como se vê na citação abaixo, retirada do site de scanlation Bleachproject:

O mangá de BLEACH é publicado no Brasil pela Panini Comics. Se baixar os capítulos aqui no site, não deixe também de adquirir o mangá oficial publicado pela editora. Assim, você incentiva o mercado brasileiro de mangás, e comprar o produto original também é uma forma de agradecer ao autor da série pelo seu trabalho. (https://bleach.zlx.com.br/multimidia/mangas/ 29/07/16)

Além disso, por se tratar de uma cultura de fãs, o próprio mangá impresso se torna um item a ser colecionado. 
ARAGÃO, S. M. - Scalation e o poder do leitor-autor na tradução de mangás

\section{Scanlation no Brasil}

A língua mais utilizada para scanlation é o inglês e inúmeros são os sites especializados na distribuição de mangás traduzidos nesse idioma. Um exemplo é o site Mangafox (http://mangafox.me/) que abriga scanlations dos mangás mais populares do momento. Alguns sites de scanlation podem utilizar textos-fonte em inglês ou espanhol de outros grupos por estas se tratarem de línguas mais acessíveis, porém, a grande maioria utiliza como texto de partida a língua japonesa.

No Brasil, o mangá é bastante popular, sobretudo aqueles direcionados para meninos (shonen), e há editoras especializadas nesse tipo de publicação, como a JBC (Japan Brazil Communication) e também outras editoras importantes de quadrinhos, como a Panini e a Conrad. Os sites de scanlation ou scantrad, como também é conhecida a prática no Brasil, disponibilizam mangás de grande sucesso como Naruto (http://boruto.com.br/index.php), One Piece (https://onepiece.zlx.com.br/) e Bleach (https://bleach.zlx.com.br/). É interessante notar que em todos os sites, além dos mangás traduzidos, é possível encontrar episódios das versões animadas também legendados pelos fãs. Ademais, os visitantes dos sites têm acesso a notícias relacionadas às séries. Os sites possuem links entre si, o que sugere que, apesar de se tratarem de scanlations de obras diferentes, todos fazem parte de uma grande e organizada equipe. Em cada um dos sites é possível encontrar os nomes dos membros (pseudônimos e nomes reais), emails para contato, as cidades de origem (há membros de várias partes do Brasil e até mesmo um de Portugal), a idade (cerca de 20 anos) e a função desempenhada no grupo (administrador, uploader, web designer e news editor).

Vale ressaltar que todos os mangás citados acima são publicados regularmente no país, isso contraria a tendência de alguns grupos de scanlators deixarem de distribuir as obras no momento em que são licenciadas

TradTerm, São Paulo, v. 27, Setembro/2016, pp. 75-113

www.usp.br/tradterm

http://www.revistas.usp.br/tradterm/index 
ARAGÃo, S. M. - Scalation e o poder do leitor-autor na tradução de mangás

para publicação. Pode-se supor que a atividade desses grupos é sustentada e motivada, principalmente, pela questão do tempo, pois as obras distribuídas nos sites são traduzidas imediatamente após a publicação no Japão. Tal aspecto coloca as editoras em desvantagem, pois muitas vezes elas demoram anos para começar a traduzir um mangá que já estava sendo lido através de scanlations, desse modo, os fãs não querem abrir mão de acompanhar a série por um período de tempo até que a editora alcance a etapa da história em que eles estavam antes da publicação. Um exemplo disso é a obra que escolhemos analisar neste artigo, o mangá shonen Fairy Tail, que começou a ser publicado em 2008 no Japão e que só três anos depois teve os direitos de publicação comprados pela editora JBC. Os títulos são publicados mensalmente pela editora em volumes com cerca de 200 páginas e, em julho de 2016, enquanto a editorada lançava o volume 53, contendo os capítulos 447 a 455, o site de scanlation da obra (https://fairytail.zlx.com.br/) já disponibilizava para download o capítulo 495. O site publica as scanlations por capítulos, que contém, em média, 20 páginas. Vale notar que os originais em japonês não são disponibilizados no site, logo, não é possível confirmar se o texto-fonte utilizado pelos scanlators brasileiros é, de fato, o japonês.

Nosso corpus de análise, formado pelo volume 10 de Fairy Tail, foi publicado pela JBC e traduzido pelo famoso dublador Guilherme Briggs (que dá voz a personagens como Optimus Prime, de Transformers, Cosmo, de Os padrinhos mágicos, Buzz Lightyear, de Toy Story, etc.). Vale ressaltar que a tradução da JBC teve como fonte a versão em inglês licenciada pela editora de mangás americana Del Rey Manga (atualmente, Kodansha Comics USA), ou seja, esta edição da obra não foi traduzida diretamente do japonês, como afirmam os realizadores das scanlations aqui expostas. Tais informações são importantes no que se refere à recepção da obra, pois conforme dito ao longo deste trabalho, há uma valorização, por parte dos fãs, de obras traduzidas diretamente da língua japonesa. Outro fator relevante reside no fato de o tradutor da editora, assim como aqueles dos grupos de scantrad, não ser um 
ARAGÃo, S. M. - Scalation e o poder do leitor-autor na tradução de mangás

profissional em tradução, apesar de ter experiência no mundo dos quadrinhos como desenhista e trabalhar com animação.

A seguir, expomos alguns exemplos de tradução do mangá Fairy Tail retirados do site de scanlation Fairyproject e a versão impressa correspondente publicada pela editora JBC. Buscaremos fazer uma comparação entre as traduções tendo em vista as principais características da scanlation arroladas neste artigo, atentando, também para as estratégias tradutórias adotadas nestas traduções, valendo-se das modalidades de tradução definidas por Aubert (1998), a saber, omissão, transcrição, empréstimo, decalque, tradução literal, transposição, explicitação, implicitação, modulação, adaptação, tradução intersemiótica, erro, correção e acréscimo. 
ARAGÃo, S. M. - Scalation e o poder do leitor-autor na tradução de mangás

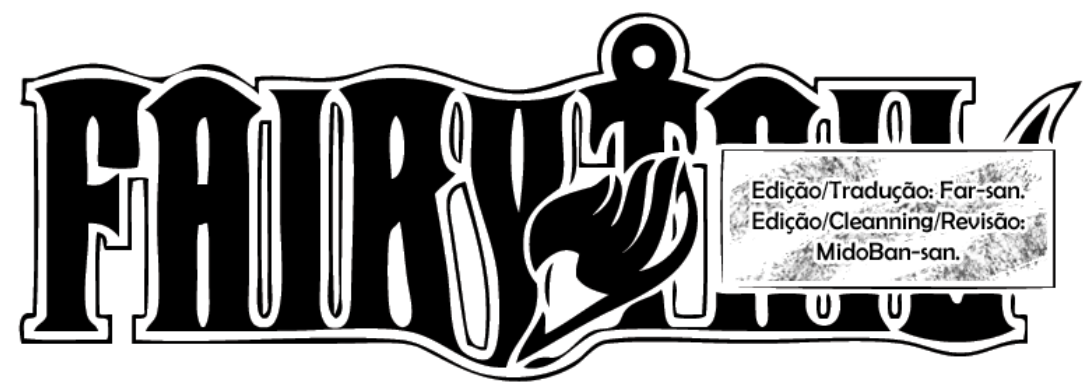

CAPÍTULO 76 "A TORRE DO PARAÍSO"

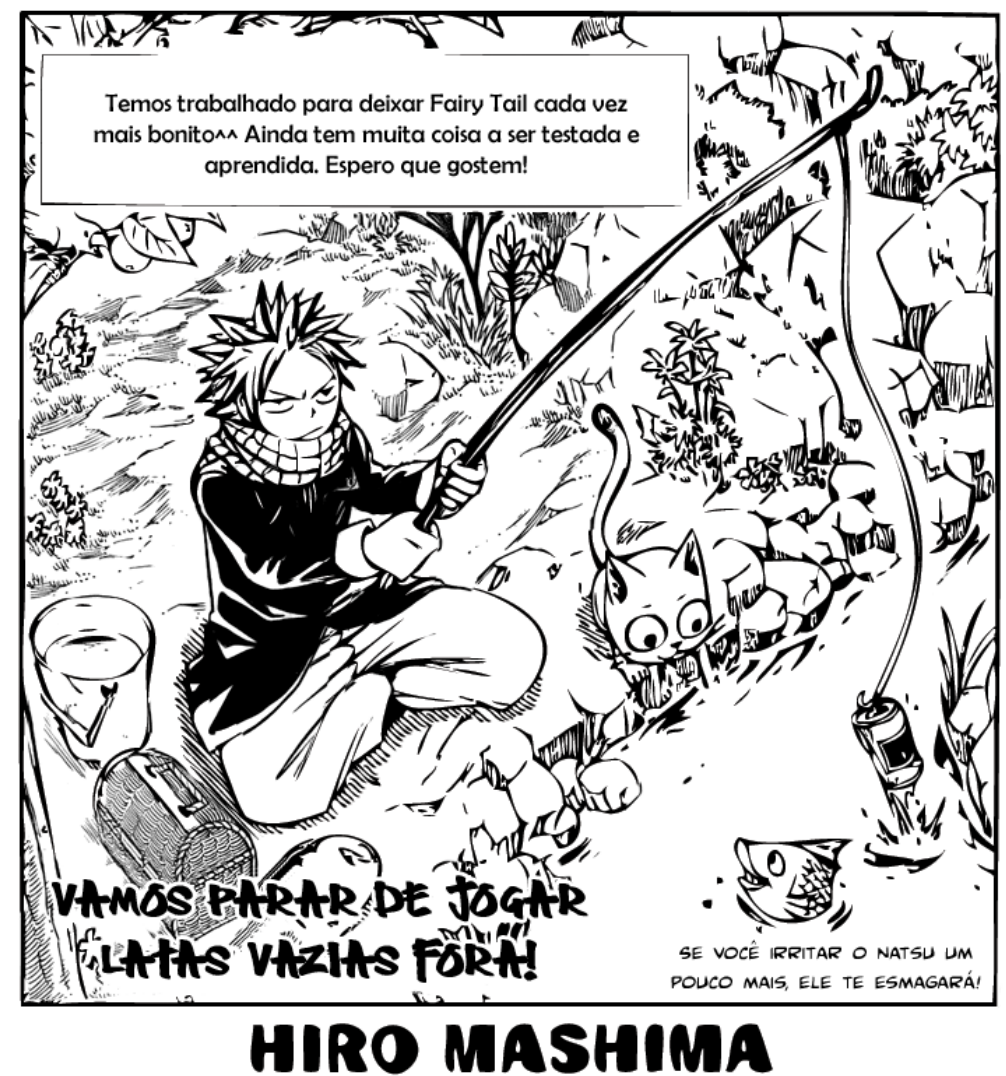

Figura 1: Extraída de https://fairytail.zlx.com.br/midia/manga/ Capítulo 76: http: / / leitor.mp/329

A figura acima exibe a folha de rosto do capítulo 76 do mangá, que contém o título e os créditos (canto superior direito), com informações sobre os responsáveis pela tradução e edição. Destaca-se, ainda, o comentário dos scanlators sobre o seu próprio trabalho (quadro inserido no desenho) 
ARAGÃo, S. M. - Scalation e o poder do leitor-autor na tradução de mangás

direcionado ao leitor: "Ainda tem muita coisa a ser testada e aprendida", o que revela o engajamento da equipe em tentar melhorar o resultado da tradução. Tais informações são, claramente, acréscimos em relação ao original, já que, segundo Aubert (1998: 109), trata-se de acréscimo "qualquer segmento textual incluído no texto alvo pelo tradutor por sua própria conta”. A seguir, vejamos como esta mesma página foi traduzida pela editora: 
ARAGão, S. M. - Scalation e o poder do leitor-autor na tradução de mangás

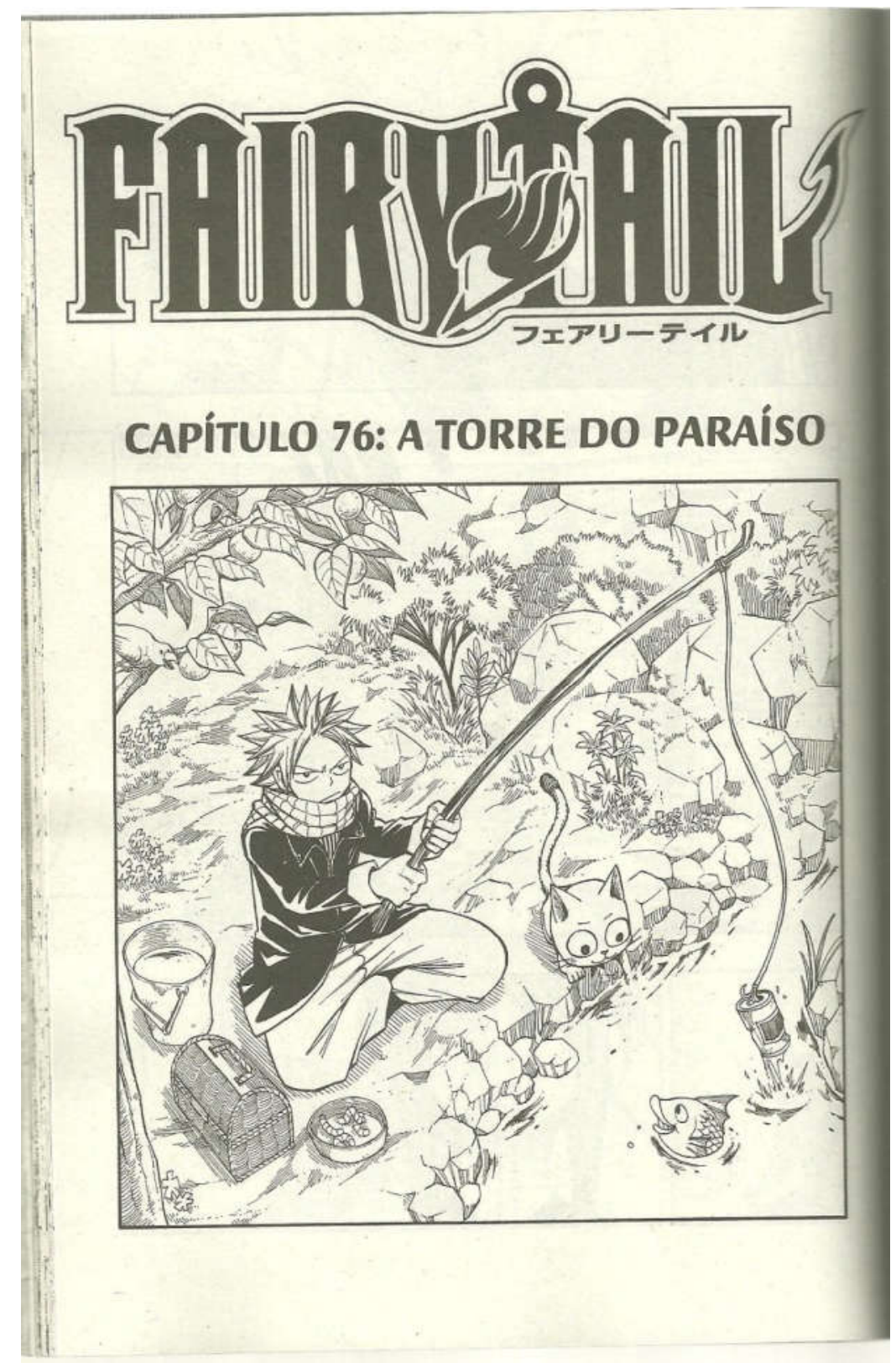

Figura 2: Extraída de Mashima, H. Fairy tail, vol. 10. São Paulo: JBC, 2011, pp.29

A versão publicada pela editora JBC contém apenas os títulos do mangá e do capítulo, ou seja, não há acréscimo de textos junto ao desenho, com informações sobre os responsáveis, ou comentários sobre a tradução. Também não consta o nome do autor, Hiro Mashima, como na scanlation, o que pode ser explicado pelo fato de a editora dispor tais informações na capa de papel 
ARAGÃo, S. M. - Scalation e o poder do leitor-autor na tradução de mangás

e no prólogo, ao contrário da versão para download, que se inicia diretamente na página de rosto. Além disso, ao compararmos a Figura 2 com a Figura 1 acima, vemos que os dizeres "Vamos parar de jogar latas vazias fora" e "Se você irritar o Natsu um pouco mais, ele te esmagará!” não constam na versão publicada pela editora. Ao observarmos a versão original em japonês abaixo, vemos que tais frases são, também, acréscimos feitos pelos scanlators a fim de atribuir um efeito de humor à cena. 
ARAGÃo, S. M. - Scalation e o poder do leitor-autor na tradução de mangás
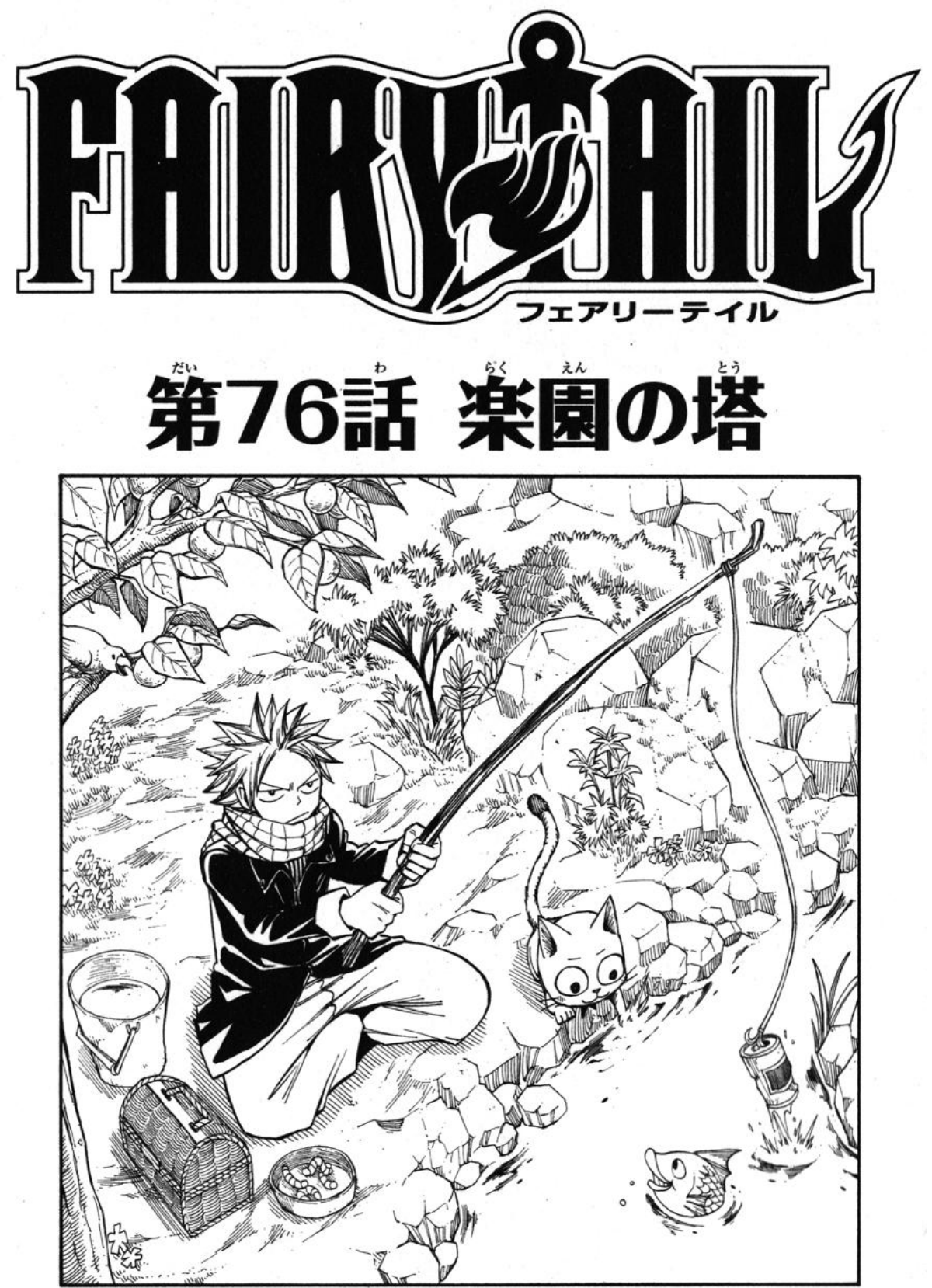

Figura 3: Extraída de http:/ / fairytail.wikia.com/wiki/Chapter_76 (28/07/16)

Abaixo, mais um exemplo de scanlation retirada do site Fairyproject: 
ARAGÃo, S. M. - Scalation e o poder do leitor-autor na tradução de mangás
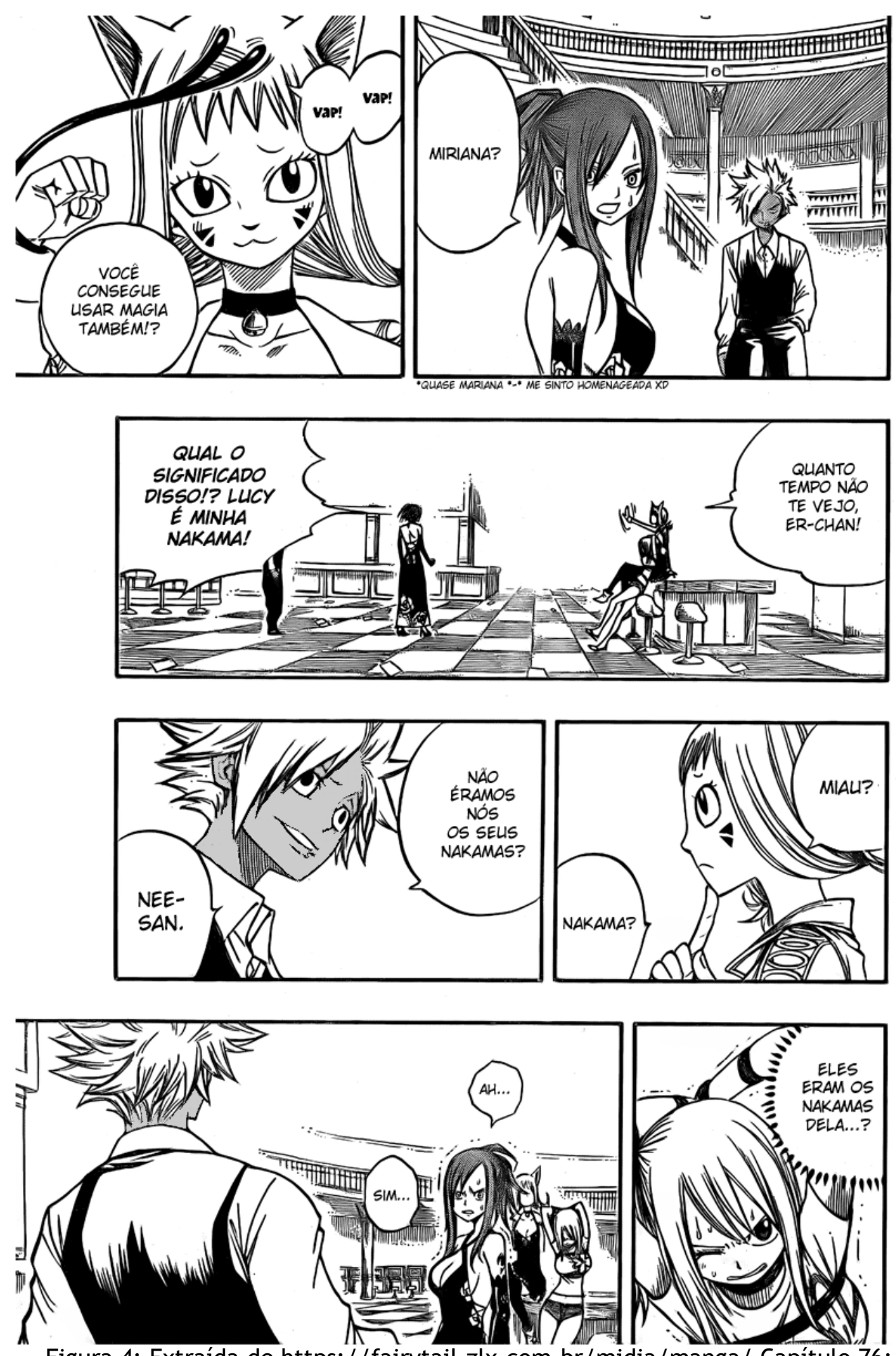

Figura 4: Extraída de https://fairytail.zlx.com.br/midia/manga/ Capítulo 76: http: / / leitor.mp/329 
ARAGÃo, S. M. - Scalation e o poder do leitor-autor na tradução de mangás

No canto superior direito, observa-se a inserção de uma nota de rodapé com um comentário da tradutora acerca do nome da personagem. Como vimos ao longo deste trabalho, o uso de notas de rodapé, apesar de não ser comum nas histórias em quadrinhos em geral, é comum nas sacanlations, principalmente para informar sobre referentes culturais japoneses que poderiam ser incompreensíveis para a maioria dos leitores ocidentais; porém, o que se vê na nota inserida na Figura 4 é um comentário de uma fã que se sente homenageada pelo fato de a personagem "Miriana" ter um nome parecido ao seu: "Quase Mariana". Outro fator a ser observado na sequência acima é o uso de decalques da língua japonesa: "nee-san" (irmã mais velha) (o sufixo honorífico "san" é mantido) e "nakama" (amigo, camarada), o que comprova a tendência das scanlations em manter palavras em japonês, de modo a conferir maior autenticidade à tradução, bem como atender uma expectativa do leitor de mangá que, em geral conhece algumas palavras ou expressões em japonês, pois, conforme afirma Jüngst (2014: 60), "uma das funções comunicativas do mangá é, de fato, fazer com que o leitor se sinta um conhecedor de mangás"² (tradução nossa). De acordo com Aubert (1998: 106), o decalque se define por:

Uma palavra ou expressão emprestada na Língua Fonte mas que (i) foi submetida a certas adaptações gráficas e/ou morfológicas para conformar-se às convenções da Língua Fonte e (ii) não se encontra registrada nos principais dicionários recentes da Língua Fonte. (idem, ibidem)

Observemos, agora, como essa mesma sequência foi publicada pela JBC:

\footnotetext{
2 "One of the communicative functions of manga is, in fact, to make the reader look like a manga connoiseur".
} 
ARAGÃo, S. M. - Scalation e o poder do leitor-autor na tradução de mangás

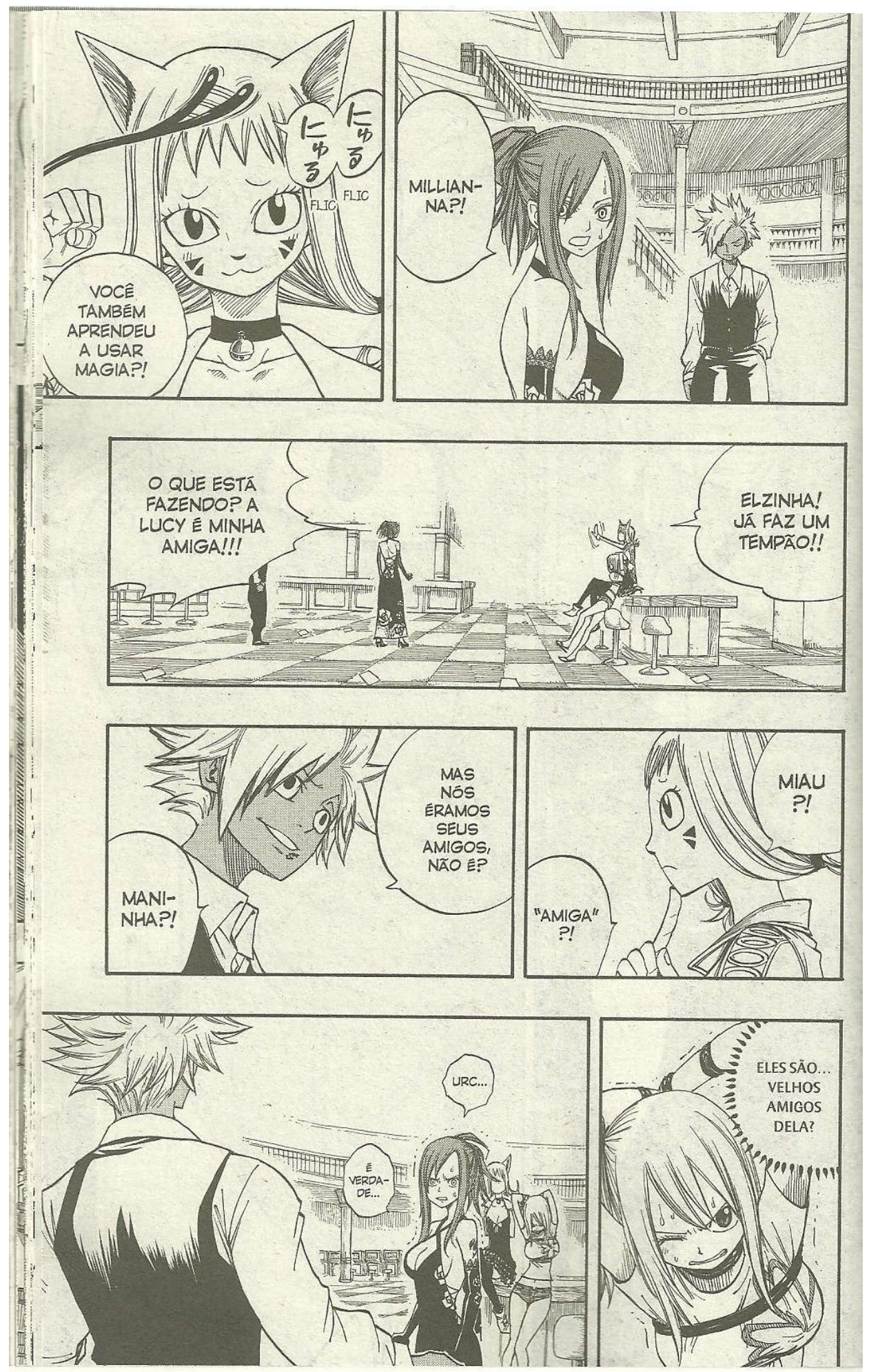

Figura 5: Extraída de Mashima, H. Fairy tail, vol. 10. São Paulo: JBC, 2011, p.39

TradTerm, São Paulo, v. 27, Setembro/2016, pp. 75-113

www.usp.br/tradterm

http://www.revistas.usp.br/tradterm/index 
ARAGÃo, S. M. - Scalation e o poder do leitor-autor na tradução de mangás

Como se pode perceber, a publicação da editora JBC apresenta o nome da personagem diferentemente, "Millianna" ao invés de "Miriana", como na Figura 4. No que se refere aos decalques em japonês "nee-san" e "nakama" presentes na scanlation, aqui, eles são traduzidos pelos termos correspondetes em português: "maninha" e "amiga", respectivamente. Apesar de Jüngst (2014: 51) afirmar que as estratégias de tradução adotadas pelas editoras tenham se modificado com o passar dos anos, diante do aumento da popularidade dos mangás e também da formação de um público leitor que deseja ter acesso a uma “japanicidade”, isto é, que a tradução se pareça o máximo possível com o original e forneça dados referenciais daquela cultura, sem adaptações, ainda é possível identificar, na tradução acima, que o uso de palavras em japonês é usado em menor frequência nas edições oficiais em comparação com as versões feitas por fãs. Ainda segundo a autora, o uso dos sufixos honoríficos "san” "soam bem japoneses para os ouvidos ocidentais e são usados em todos os tipos de filmes que retratam ou se passam no Japão”3 (JüNGST 2014: 68, tradução nossa).

A seguir, mais uma sequência traduzida pela equipe de Fairyproject:

\footnotetext{
3 "[The honorifics] sound very Japanese to the Western ears and are also used in all kinds of films that deal with or take place in Japan".
} 
ARAGÃo, S. M. - Scalation e o poder do leitor-autor na tradução de mangás
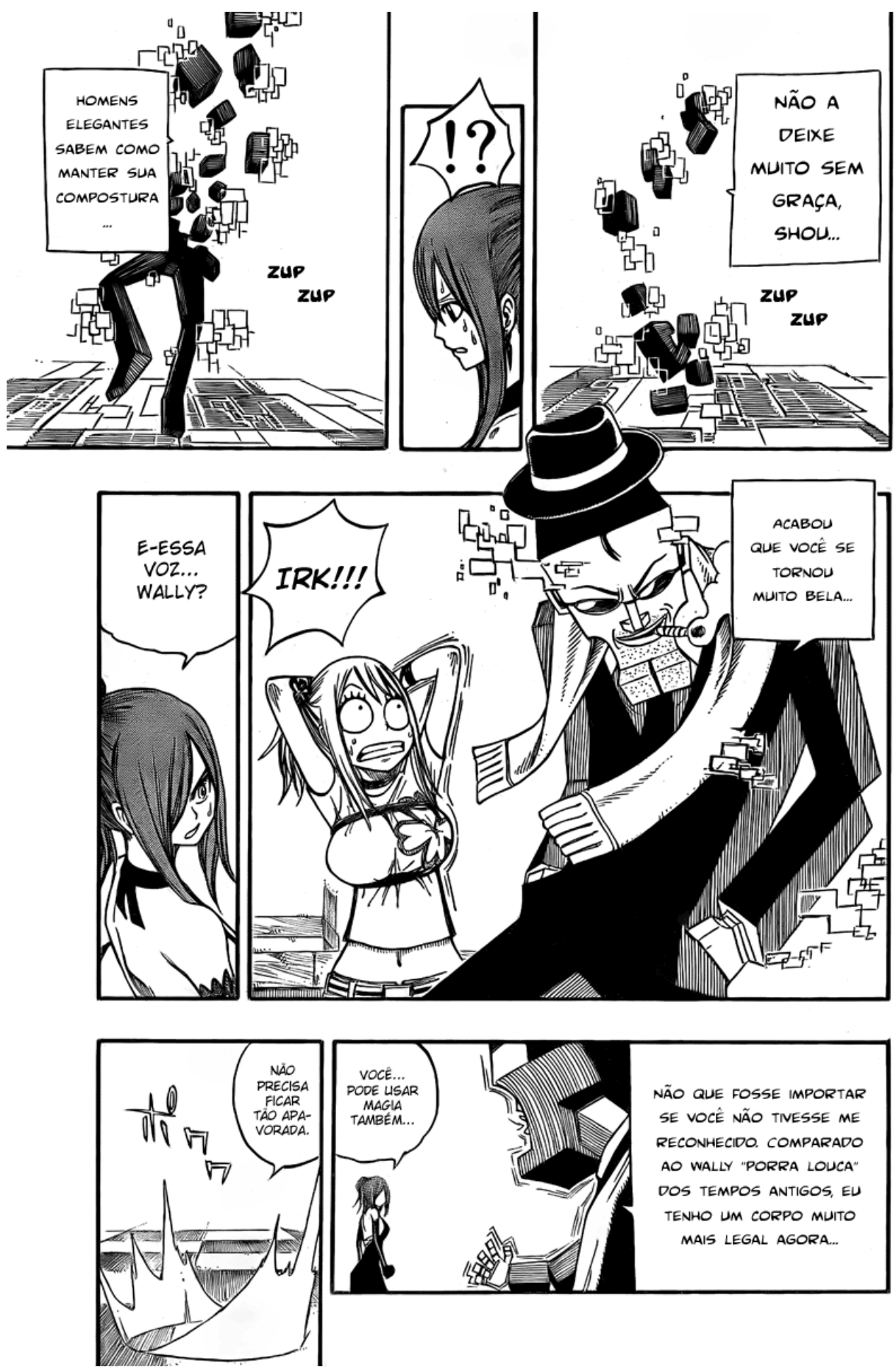

Figura 6: Extraída de https://fairytail.zlx.com.br/midia/manga/ Capítulo 76: http:/ / leitor.mp/329 
ARAGÃo, S. M. - Scalation e o poder do leitor-autor na tradução de mangás

$\mathrm{Na}$ Figura 6, é possível observar, no último quadrinho à direita, o uso da expressão de baixo calão "porra louca", que quer dizer inconsequente. 0 uso desse tipo de linguagem é relativamente comum nas scanlations por não haver censura das editoras. Vale ressaltar que as editoras também devem adequar a linguagem utilizada à faixa etária para a qual a obra é direcionada, o que não ocorre com as scanlations. No caso de Fairy Tail, a classificação etária definida pela editora no Brasil é de 14 anos.

Observemos como este mesmo trecho foi traduzido pela editora brasileira: 
ARAGÃo, S. M. - Scalation e o poder do leitor-autor na tradução de mangás

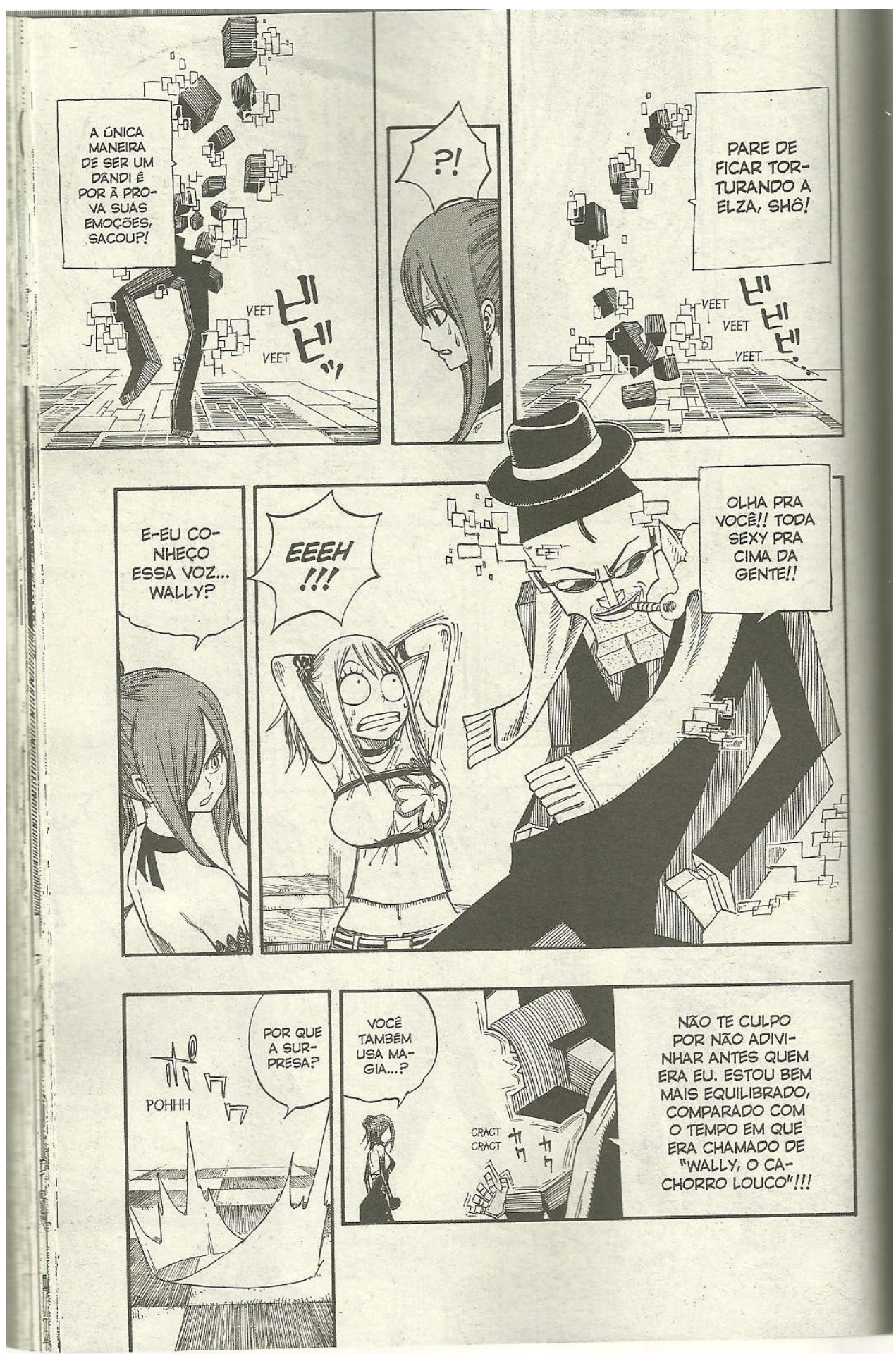

Figura 7: Extraída de Mashima, H. Fairy tail, vol. 10. São Paulo: JBC, 2011, pp. 41

TradTerm, São Paulo, v. 27, Setembro/2016, pp. 75-113

www.usp.br/tradterm

http://www.revistas.usp.br/tradterm/index 
ARAGÃo, S. M. - Scalation e o poder do leitor-autor na tradução de mangás

$\mathrm{Na}$ versão publicada pela editora JBC, a expressão que denota inconsequência utilizada é "cachorro louco", que possui um tom menos vulgar que a da versão da Internet. Porém, é interessante notar que ambas as traduções propõem expressões populares e coloquiais, o que aproxima os diálogos dos personagens à fala dos leitores em geral.

Analisemos mais uma scanlation: 
ARAGÃo, S. M. - Scalation e o poder do leitor-autor na tradução de mangás
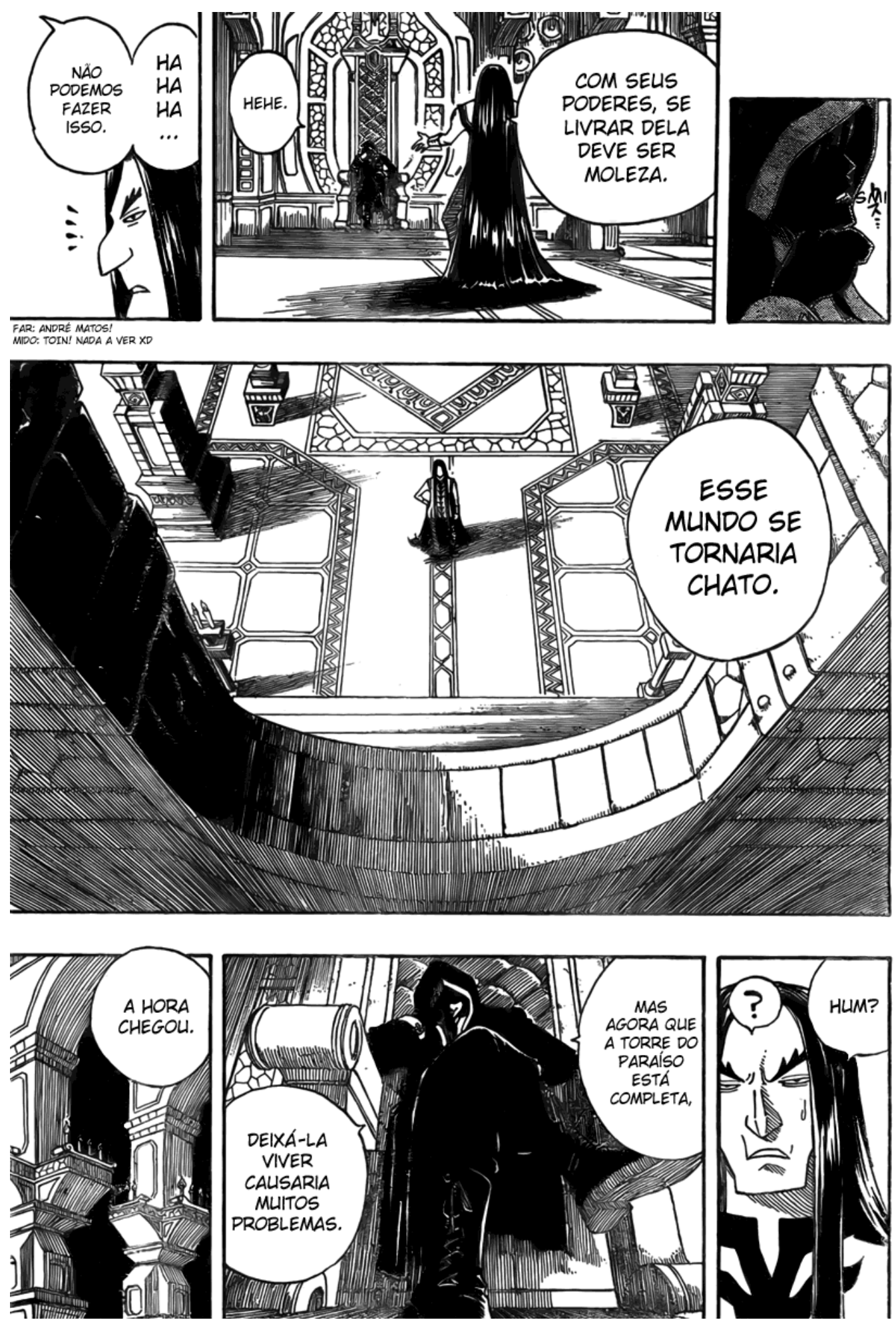

Figura 8: Extraída de https://fairytail.zlx.com.br/midia/manga/ Capítulo 77: http://leitor.mp/330

TradTerm, São Paulo, v. 27, Setembro/2016, pp. 75-113

www.usp.br/tradterm

http://www.revistas.usp.br/tradterm/index 
ARAGÃo, S. M. - Scalation e o poder do leitor-autor na tradução de mangás

No canto superior esquerdo, é possível observar a inserção de mais uma nova de rodapé feita pelos scanlators que, assim como na Figura 4, não explica um determinado vocábulo ou referente cultural ao leitor, como é de costume na prática de tradução profissional. A nota na sequência acima reproduz o diálogo entre dois membros da equipe do site, em que um deles alude ao cantor de rock brasileiro André Matos que, assim como o personagem, possui cabelos pretos e longos. Novamente, percebe-se 0 acréscimo de informações na tradução que, neste caso, introduz um elemento de humor. A referência a uma personalidade brasileira também estabelece uma relação de identidade com o leitor que não existe na obra original. Além disso, nota-se também o uso da gíria "moleza" (que indica algo fácil) no segundo quadrinho da primeira fileira, o que, paralelamente ao que ocorre nas Figuras 6 e 7, tenta reproduzir uma fala mais coloquial e mais próxima da do leitor.

Abaixo, temos a versão traduzida pela JBC: 
ARAGÃo, S. M. - Scalation e o poder do leitor-autor na tradução de mangás

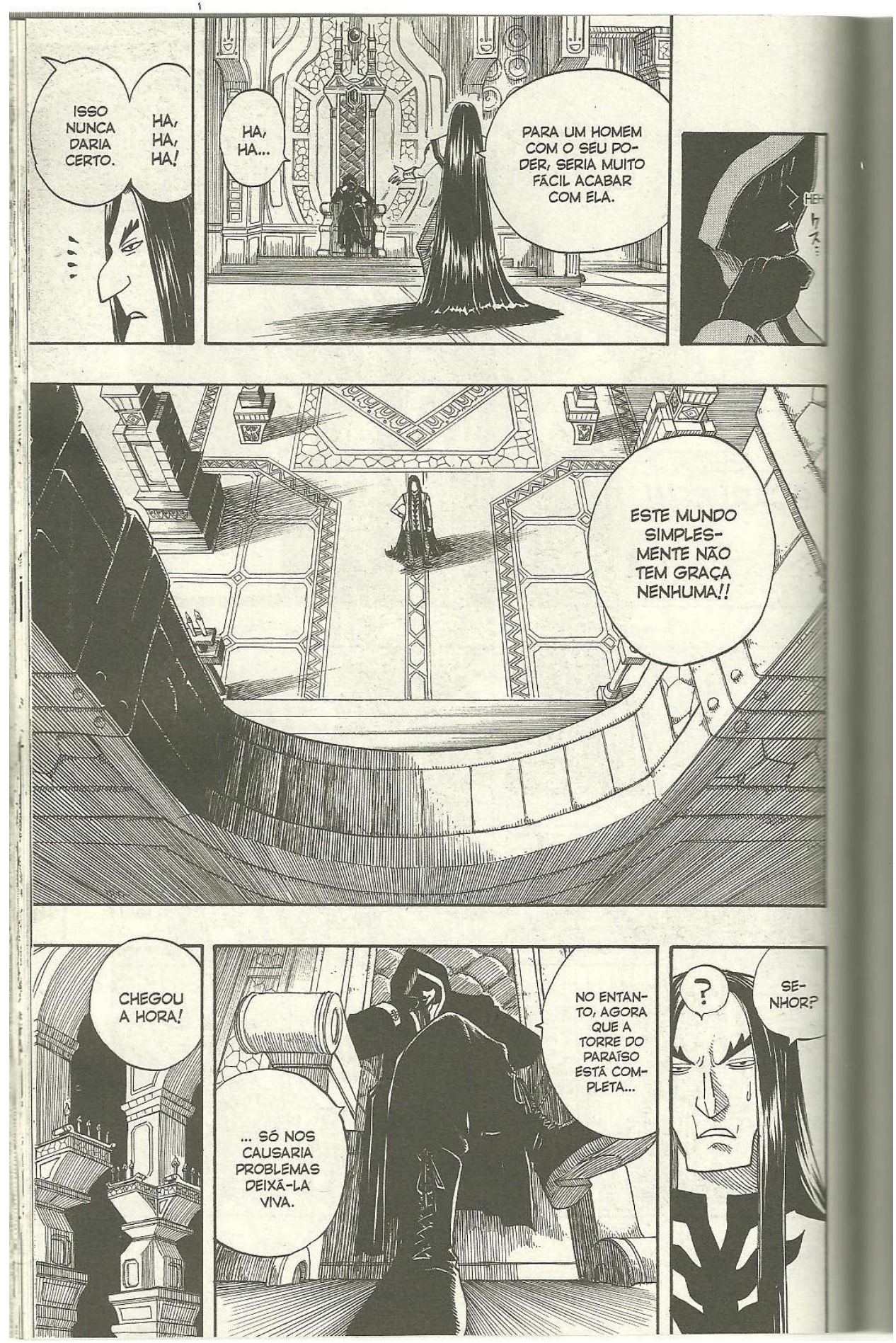

Figura 9: Extraída de Mashima, H. Fairy tail, vol. 10. São Paulo: JBC, 2011, pp. 61

TradTerm, São Paulo, v. 27, Setembro/2016, pp. 75-113

www.usp.br/tradterm

http://www.revistas.usp.br/tradterm/index 
ARAGÃo, S. M. - Scalation e o poder do leitor-autor na tradução de mangás

A sequência acima, com a tradução da Editora JBC, não apresenta nenhuma nota de rodapé acerca da aparência do personagem. No que se refere à tradução do segundo quadrinho, vê-se a palavra "fácil”, termo mais neutro em comparação com "moleza”, utilizado na Figura 8.

Abaixo, mais um exemplo retirado do site de Fairyproject:

TradTerm, São Paulo, v. 27, Setembro/2016, pp. 75-113

www.usp.br/tradterm

http://www.revistas.usp.br/tradterm/index 


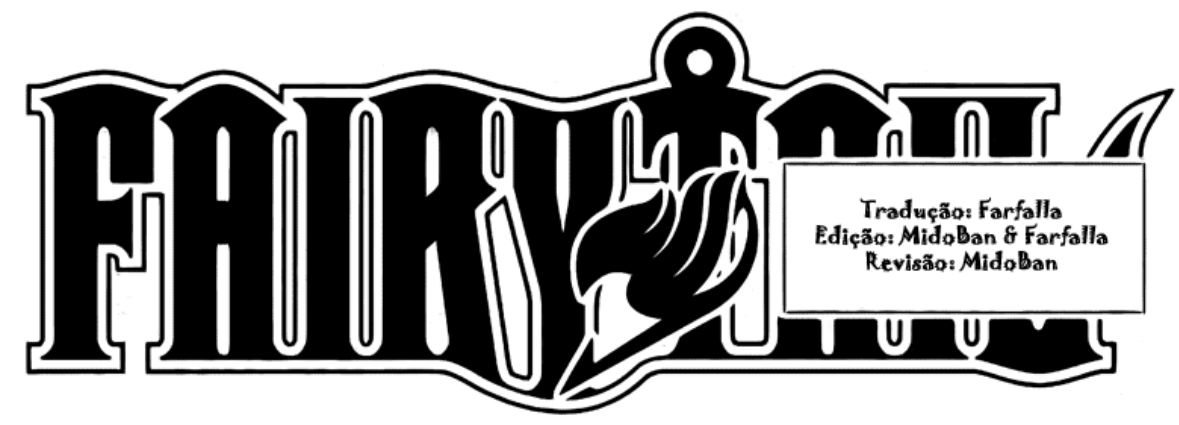

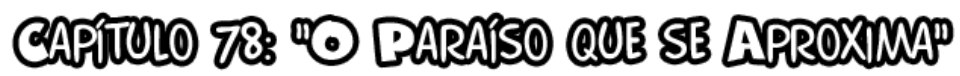

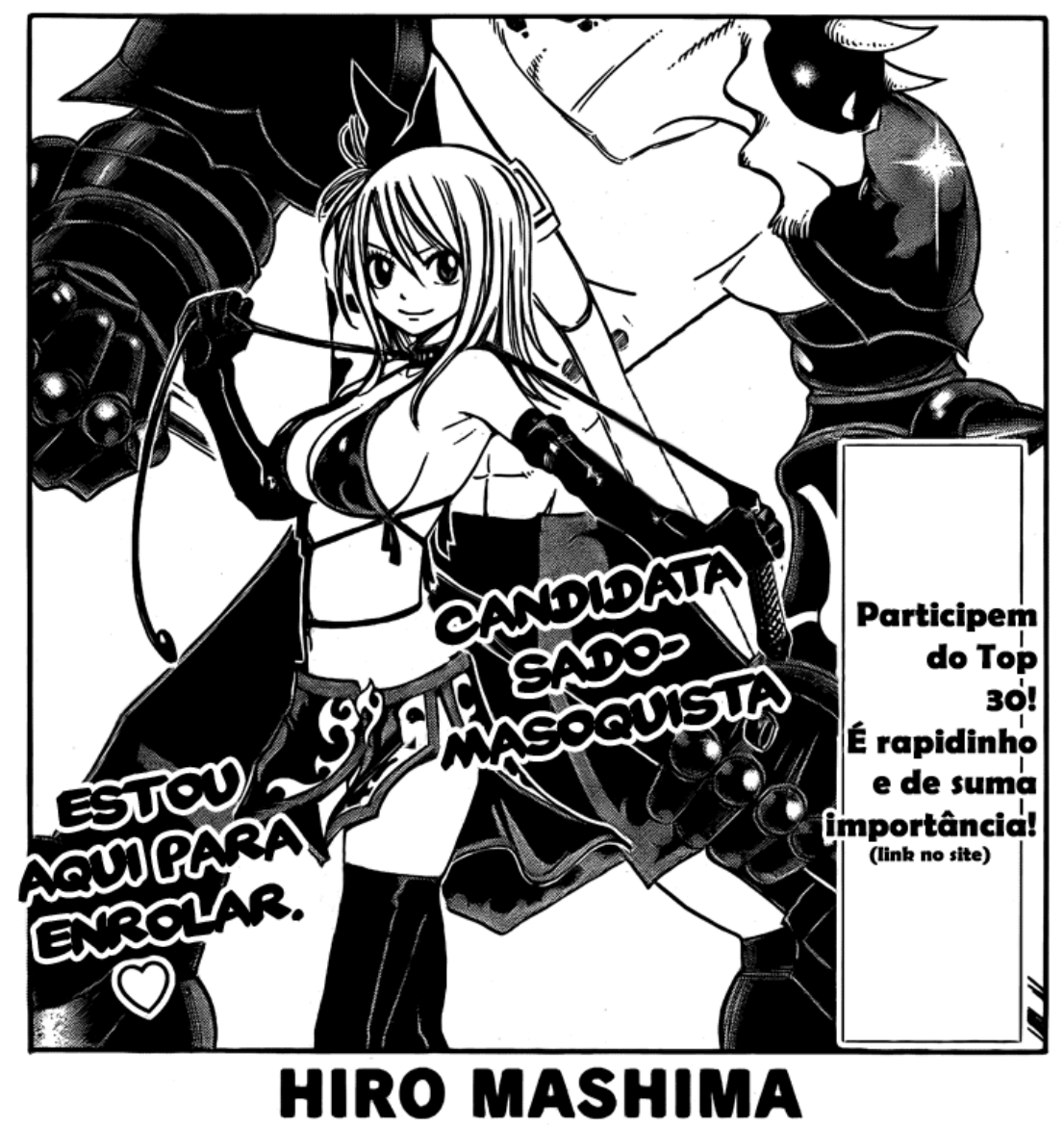

Figura 10: Extraída de https://fairytail.zlx.com.br/midia/manga/ Capítulo 78: http: / / leitor.mp/332 
ARAGÃo, S. M. - Scalation e o poder do leitor-autor na tradução de mangás

A Figura 10 apresenta a folha de rosto do capítulo 78 que, assim como a Figura 1 acima, também apresenta os créditos com os responsáveis pela tradução do capítulo. Como mencionamos anteriormente, as scanlations são realizadas por capítulos, diferente dos volumes impressos que, em geral, são formados por sete capítulos. Este pode ser um dos fatores que explicam as mudanças constantes de tradutores, o que acarreta em trocas de nomes de personagens, como veremos na Figura 13 a seguir. Além dos acréscimos semelhantes aos observados na Figura 1: "estou aqui para enrolar" e "candidata sado-masoquista" (comentário irônico a respeito das roupas e do chicote da personagem), que não constam na versão em japonês (cf. Figura 12 abaixo), há menção a uma enquete no site que realiza as traduções. Pode-se dizer que a indicação da enquete se trata de um recurso de publicidade com o objetivo de propiciar a comunicação entre os fãs e também promover o próprio grupo. Conforme dito ao longo deste trabalho, os scanlators são fãs que formam redes de contato, logo, a participação de outros fãs nos sites por meio de enquetes e fóruns de discussão são práticas frequentes.

A seguir, a tradução publicada pela editora oficial: 
ARAGÃo, S. M. - Scalation e o poder do leitor-autor na tradução de mangás

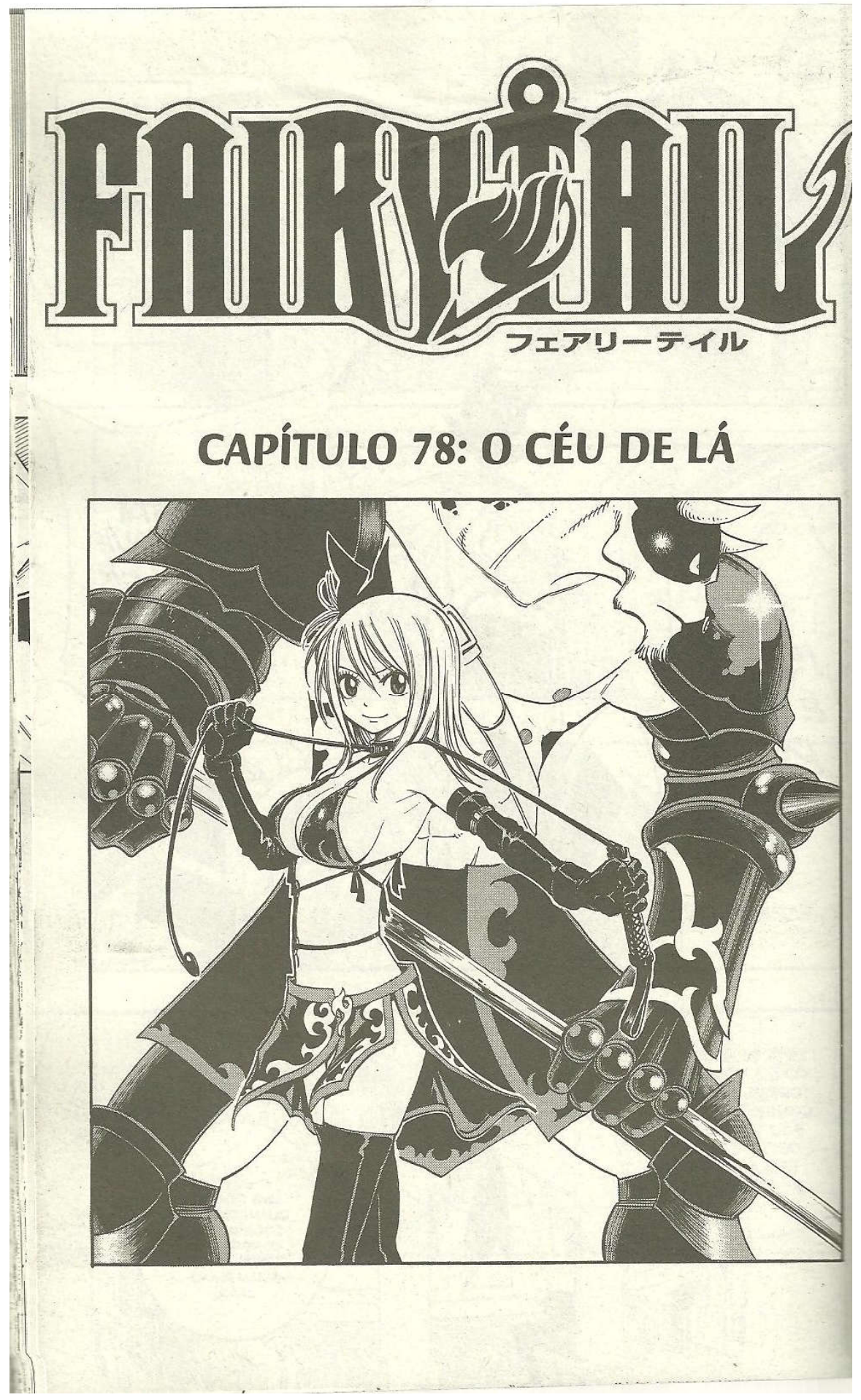

Figura 11: Extraída de Mashima, H. Fairy tail, vol. 10. São Paulo: JBC, 2011, pp. 69

TradTerm, São Paulo, v. 27, Setembro/2016, pp. 75-113

www.usp.br/tradterm

http://www.revistas.usp.br/tradterm/index 
ARAGÃo, S. M. - Scalation e o poder do leitor-autor na tradução de mangás

A tradução publicada pela JBC é composta apenas pelos títulos do mangá e do capítulo, conforme o original em japonês que expomos abaixo:
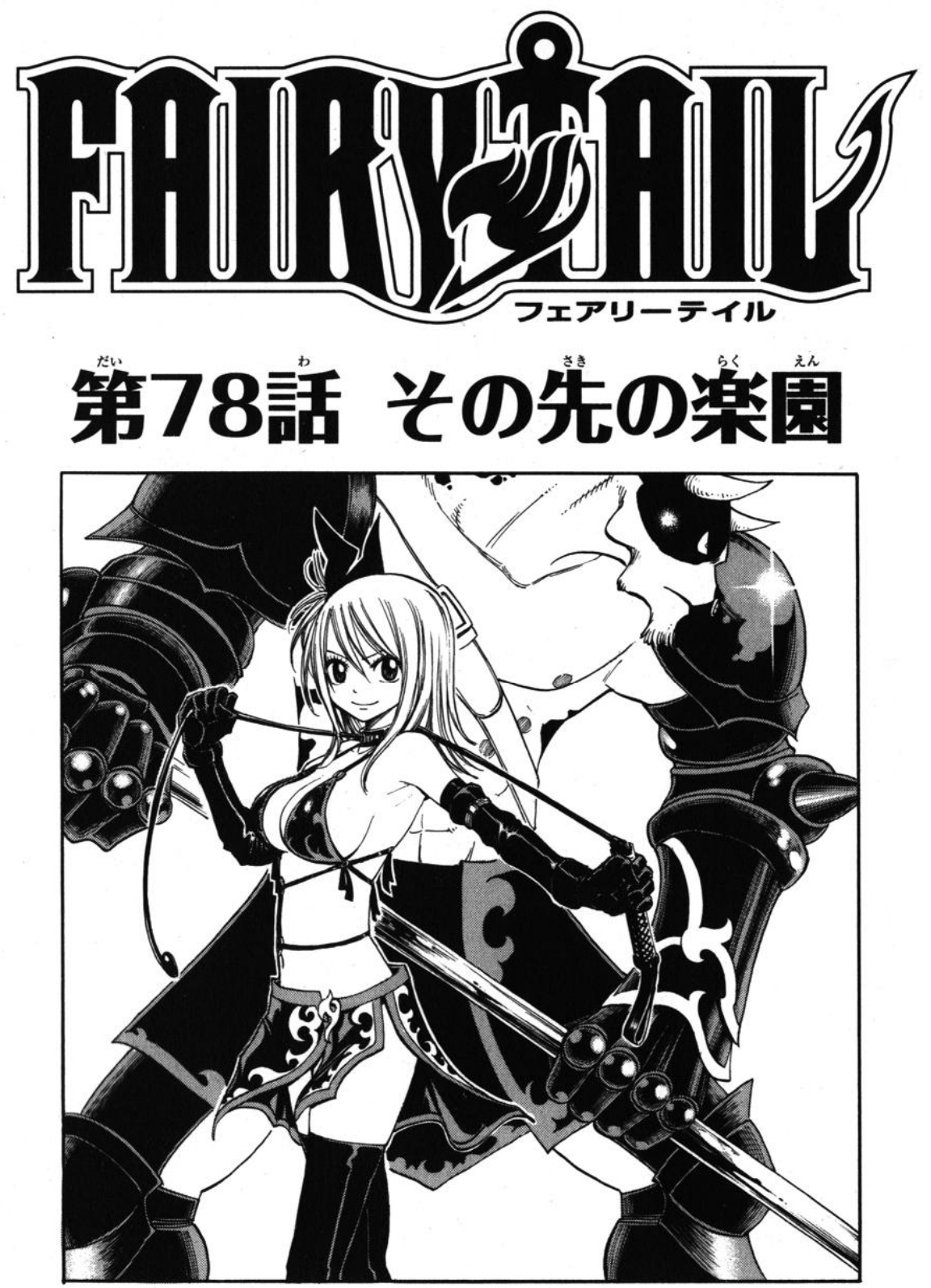

Figura 12: Extraída de

http: / / fairytail.wikia.com/wiki/Chapter_78?file=Cover_78.JPG (29/07/16)

Abaixo, podemos conferir a última sequência analisada neste trabalho: 
ARAGÃo, S. M. - Scalation e o poder do leitor-autor na tradução de mangás
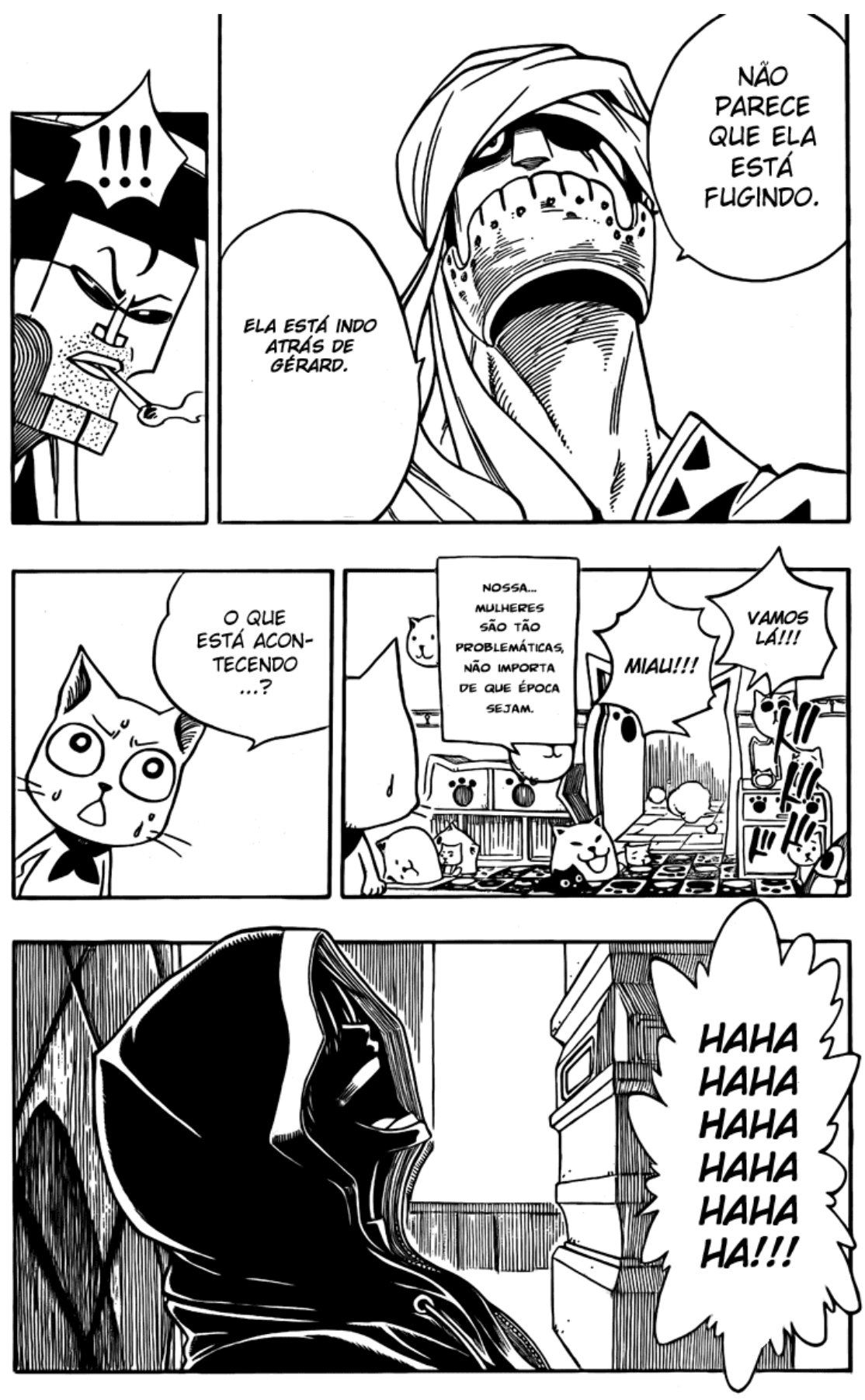

Figura 14: Extraída de https://fairytail.zlx.com.br/midia/manga/ Capítulo 78: http://leitor.mp/332 
ARAGÃo, S. M. - Scalation e o poder do leitor-autor na tradução de mangás

Conforme mencionado acima, as scanlations são feitas por capítulo e distribuídas nos sites à medida que estes são publicados no Japão, o que pode explicar a troca constante de tradutores de capítulo para capítulo. No caso da Figura 14 acima, há mudança no nome do personagem que aparece nos capítulos anteriores como "Jeral" e nesta como "Gérard". De acordo com Aubert (1998: 108), este seria um caso de erro, pois:

[...] somente os casos evidentes de 'gato por lebre' incluem-se nesta modalidade [...]. Esta categoria não abarca, portanto, as soluções tradutórias percebidas como 'inadequadas', estilisticamente inconsistentes, etc. (idem, ibidem)

Infere-se que, mesmo que haja responsáveis pela edição e revisão das scanlations, estes não realizam um cotejo com os capítulos já publicados de forma sistemática, nem elaboram glossários, como ocorreria em um contexto de tradução profissional.

Vejamos a seguir a tradução realizada pela editora brasileira: 
ARAGÃo, S. M. - Scalation e o poder do leitor-autor na tradução de mangás

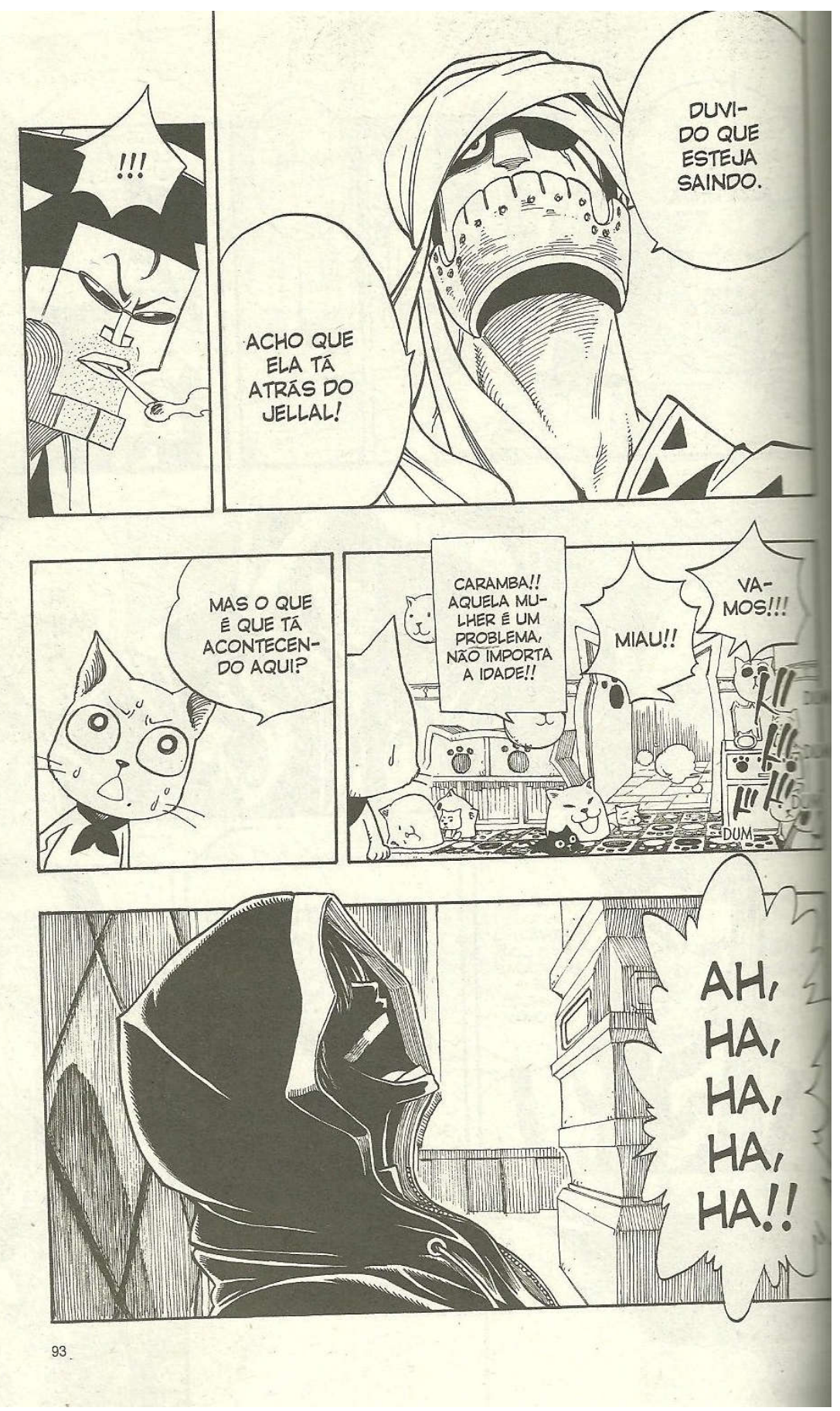

Figura 15: Extraída de Mashima, H. Fairy tail, vol. 10. São Paulo: JBC, 2011, pp. 93

$\mathrm{Na}$ versão publicada pela editora JBC mantém-se o mesmo nome do personagem (Jellal) em todas as páginas do volume. Conforme apontado 
ARAGÃo, S. M. - Scalation e o poder do leitor-autor na tradução de mangás

anteriormente, há diferenças significativas no processo de tradução em uma editora, pois o volume é lançado integralmente e é feito por um mesmo tradutor, o que contribui para que não haja variação e erros na tradução de elementos recorrentes na obra.

\section{Considerações finais}

Em linhas gerais, os estudos relacionados à análise da scanlation merecem maior aprofundamento, pois, conforme foi possível observar neste breve ensaio, essa prática apresenta um terreno fértil para a investigação científica, seja em relação ao processo de tradução e distribuição, seja nos aspectos formais e linguísticos das traduções ou, ainda, no que se refere ao papel do leitor nesse processo. Vimos que, no Brasil, a prática da scanlation apresenta algumas peculiaridades e semelhanças com as scanlations realizadas em outros países.

Por fim, pudemos observar algumas características da scanlation e suas implicações no mercado editorial, bem como seu impacto na recepção das obras por parte dos leitores. Desse modo, é possível afirmar que a prática da tradução realizada por fãs em um meio virtual de grande circulação aponta para uma nova forma de se traduzir, haja vista a participação efetiva dos leitores que acabam por se transformar em coautores das obras.

Como pudemos observar nos exemplos, há uma apropriação da obra, o que revela uma relação de identificação entre tradutores e leitores, haja vista a presença de anúncios do grupo de scanlators, elementos culturais e linguísticos que apelam para o conhecimento do leitor, etc. No que se refere às estratégias tradutórias, destaca-se o uso de acréscimos, seja em notas de rodapé, seja no próprio quadro que, como vimos, buscam causar humor ou promover a comunicação com os leitores. Os decalques em língua japonesa também são utilizados em maior frequência nas scanlations do que nas 
ARAGÃo, S. M. - Scalation e o poder do leitor-autor na tradução de mangás

versões traduzidas pela editora brasileira por nós analisada. Os casos de erro na tradução aqui analisados resultam provavelmente do fato de não haver um trabalho de revisão entre os diferentes capítulos publicados nos sites e também por não haver, provavelmente, a elaboração de glossários e fichas, como ocorreria em um contexto de tradução profissional de uma editora.

Por fim, um trabalho motivado pelo gosto pessoal do tradutor estabelece uma nova relação com o leitor daquela obra. A scanlation se configura como um texto dinâmico online que conta com a participação dos fãs e pode ser alterado a partir da opinião destes. Este é um desejo que muitos leitores de literatura estrangeira já tiveram em algum momento de suas vidas: o poder de transformar a tradução, o poder de dialogar com o tradutor, o poder de construir, junto com ele, uma obra por ambos apreciada.

\section{Referências bibliográficas}

AUBERT, F. H. Modalidades de Tradução: teoria e resultados. In: TradTerm, São Paulo, v. 5, n. 1, 1998, pp. 99-128.

HIRATA, T. \& GUSHIKEN, Y. Scanlation: Prática midiática de fãs e a circulação de mangás na cibercultura. XIII Congresso de Ciências da Comunicação na Região Centro-Oeste, 2011. Disponível em:

http://intercom.org.br/papers/regionais/centrooeste2011/resumos/R270061-1.pdf. Acesso em: 28 jul. 2016.

JÜNGST, H. Translating manga. In: ZANETTIN, F. Comics in translation. New York: Routledge, 2014: 50-78.

LEE, H-K. Between fan culture and copyright infringement: manga scanlation. Media, Culture \& Society. Los Angeles, London, New Delhi and Singapore: Sage Publications, Vol. 31(6), 2009: 1011-1022.

MANOVICH, L. et al. Understanding scanlation: how to read one million fantranslated manga pages. In: Image and narrative, vol. 12, n. 1, 2011, pp. 190227. Disponível em: 
ARAGÃo, S. M. - Scalation e o poder do leitor-autor na tradução de mangás

http://www.imageandnarrative.be/index.php/imagenarrative/article/view/1 33. Acesso em: 28 jul. 2016.

O'HAGAN, M. Evolution of user-generated translation: fansubs, translation hacking and crowdsourcing. The Journal of Internationalisation and Localisation. Vol. 1, 2009, pp. 94-121.

Simó, M. R. F. Fansubs y scanlations: la influencia del aficionado en los criterios profesionales. Puentes. n 6, 2005: 27-44. 